\title{
Development of Economic Assessment of Technologies
}

Aleksandr Mikhaylovich Batkovskiy ${ }^{1}$

Mikhail Aleksandrovich Batkovskiy²

Pavel Vasilyevich Kravchuk ${ }^{3}$

\section{Elena Georgievna Semenova ${ }^{4}$}

\begin{abstract}
Alena Vladimirovna Fomina ${ }^{1}$
1 Joint Stock Company "Central Research Institute of Economy, Management and Information Systems "Electronics ", Moscow, Russian Federation

2Federal State Unitary Enterprise "Mytishchi Research Institute of Radio Equipment", Moscow, Russian Federation ${ }^{3}$ All-Union Institute of Fiber-optic Communication Systems and Information Processing, Moscow, Russian Federation ${ }^{4}$ The Department of Innovation and Quality Management, St. Petersburg State University of Aerospace Instrumentation, St. Petersburg, Russian Federation Email: batkovskiy_a@instel.ru
\end{abstract}

\section{Doi:10.5901/mjss.2015.v6n4s4p22}

\section{Abstract}

This article presents various theoretical and methodological approaches to technology assessment, which are applied in Russia and abroad. It classifies and describes the milestones of development of such assessment methodology and tools in our country, covering the period from 1960s till present. The article provides results of analysis of technology assessment methods and techniques, which are used in Russia and abroad. Fundamental differences between technology assessment indicators, which are based on the cost and discounted cost concepts, and indicators, which are based on the opportunity cost concept, were determined. Analysis of development of methods and models of economic assessment of technologies points out to their consistency. In their economic essence, all of them are based (in the modern context) on the same general methodology of assessment of results and costs in different combinations and modifications thereof. However, existing assessment methods do not allow to assess (in an integrated manner) dual-use technologies, which are widely applied in Russia. Therefore, we offered a new integrated approach to development of the methodology and tools of economic assessment of technologies applied in various sectors of the economy (civil and military). The tools for implementation of such approach were developed in a form of economic and mathematical models. They allow to estimate an integrated economic effect of technologies when used in civil and military sectors, which is very important in the current situation. Practical application of such models will allow to assess (in a systemic manner) the effects from creation and implementation of dualuse technologies. The article identifies basic trends in further study of this applied research task and the most acceptable methods thereof.

Keywords: assessment, efficiency, products, technology, methods, tools, models.

\section{Introduction}

In 1960-1980s, economic assessment of technologies in the Soviet Union was based (for the most part) on industry, interdepartmental and nationwide methodologies, which used the concepts and methods generally accepted at that time. Such assessment was based on the indicators related to reduction of full costs of the processes performed using specific types of technologies, which were compared with capital expenditures which resulted in such reduced costs. All economic assessments were made in respect of certain types of technologies used in manufacturing of specific products, as well as in respect of the processes of their development, implementation and upgrading. The issues of assessment of commercial efficiency of new technologies implementation were the least elaborated issues in the economic theory in those years, since such issues were pretty much ignored in command economies. Faced with this problem, there were no reliable statistical indicators and clear definitions of applied categories, e.g. the concept of "novelty" had no clear assessment criterion. Such circumstances prevented from getting objective assessments of the efficiency of technological development of the national economy and its industries (Konson, A., 1968). 
About 30 years ago, the Soviet Union started to adopt the internationally accepted methods of economic assessment of technologies, which were based on the so called methodology of the United Nations Industrial Development Organization (UNIDO). The key point of this methodology is the opportunity cost concept, which integrates the law of supply and demand (Hansen, J.R., 1974). Nationwide adoption of UNIDO methodology included 3 main phases. Phase 1 was related to implementation of the Integrated Methods of Assessment of Efficiency of Measures Aimed at Acceleration of Scientific and Technical Progress in 1988 (MP-1988) (Postanovlenie, 1988). Phase 2 was related to implementation of the Guidelines for Assessment of Efficiency of Investment Projects and Their Selection for Financing in 1994 (MP-1994) (Metodicheskie, 1994). Phase 3 started in 2000, when the second edition of the Guidelines for Assessment of Efficiency of Investment Projects and Their Selection for Financing was implemented (MP-2000) (Metodicheskie, 1999).

Despite significant differences between the above methodological recommendations, they determine the procedure for assessment of efficiency of new technologies' development without comprehensive consideration of issues related to commercial efficiency of their realization in the market (Andreychikov, A., and Andreychikova, O., 2015). Such circumstance reduces the importance of existing methods and tools of economic assessment of technologies. Therefore, the importance of the task under consideration requires further research.

\section{Literature Review}

\subsection{Review of Regulatory and Procedural Documents}

Development of the methodological basis of economic assessment of technologies may be described by results of comparative analysis of the above regulatory documents (MP-1988, MP-1994 and MP-2000). Main differences between them are as follows: in MP-1988, assessment objects include certain measures and actions (works, services, technologies, management operations and solutions) focusing on achievement of targets related to productivity enhancements, acceleration of scientific and technological progress etc. In MP-1994 and MP-2000, the assessment object includes investments in specific projects described by their scales, accounting periods, financial needs etc. Local measures, products and technologies are "hidden" behind investments in MP-1994 и MP-2000 (Balyberdin, V. et al., 2014).

We should mention very important aspects of MP-1994, and especially MP-2000, which are related to future requirements to the methods of economic assessment of technologies. Such aspects include quite detailed and deep consideration of the issues of assessment of investment projects from the standpoint of their parties, as well as with due account for various risks.

In MP-2000, efficiency of an investment project is thought of as a category showing the project's compliance with the goals and interests of its parties. Revenues and costs of such parties determine different types of efficiency of investment projects focusing on development of new technologies. MP-2000 suggests to assess the overall efficiency of a project and efficiency of participation in an investment project. Project efficiency is generally assessed in order to determine its attractiveness for potential participants, and in order to raise capital. It includes social (social and economic) and commercial efficiency. Social efficiency indicators take into account social and economic consequences of investment project implementation for the society in general. Project's commercial efficiency indicators take into account financial consequences of project implementation for the parties of the investment project, assuming that they incur all costs necessary for project implementation and benefit from all results of the project. According to MP-2000, efficiency of project participation is determined in order to check the investment project's feasibility and interest of all its parties therein. It includes:

- efficiency of companies' participation in the project (investment project efficiency for the participating companies);

- $\quad$ efficiency of investment in companies' shares (efficiency for shareholders of the participating companies);

- efficiency of project participation for entities of higher level as compared with the companies participating in the investment project, including: regional and macroeconomic efficiency - for certain regions and the national economy; industry efficiency - for specific industries of the national economy and associations;

- budget efficiency of investment projects (efficiency of government's involvement with regard to costs and revenues of budgets at all levels).

We should mention that project efficiency for a specific participant is determined, subject to MP-2000, by the ratio (taking into account the time difference) of its equity invested in the project and the capital received by it from realization of the project and remaining at its disposal (after compensation of its own costs and settlements with other parties: 
creditors, state etc.). In general, the structure of costs and benefits, as well as the applied discount rates may significantly vary for different parties. According to MP-2000, risks mean the probability of circumstances which will result in adverse consequences for all or some parties of the project, and uncertainties mean incompleteness and inaccuracy of information about the project implementation terms. Project implementation scenario, in respect of which efficiency estimates were made, will be deemed as a primary (base) scenario, and all other possible scenarios will be considered as scenarios resulting in positive or negative deviations from the efficiency indicators values used in the base scenario. Presence or absence of a risk related to realization of a particular scenario is determined by each project party based on the value and sign of relevant deviation. We should mention that MP-2000 provides alternative interpretation of risk as any possible deviations (positive or negative) from the planned average values thereof. Therefore, the estimates use moderately pessimistic indicators (rather than the average indicators) when developing the base scenario of implementation of the project focusing on development of new technology.

MP-2000 provides for assessment of projects in an uncertain environment using the following methods: consolidated assessment of sustainability; calculation of breakeven points; parameter variation method; expected effect assessment with account for quantitative parameters of uncertainty. All methods, except for the first one, provide for development of project implementation scenarios under the most probable or most dangerous (for any parties) conditions and estimation of the financial consequences of such scenarios. This allows to make a provision for remedial measures or loss reallocation measures within the project, if necessary (Batkovskiy, A., 2011).

The problem of development and assessment of technologies, as well as the issues of dual-use technologies are widely considered in some foreign sources, including official documents, research reports, collective and individual studies. Various aspects of dual-use technologies are analyzed in the European Commission report - (EU Funding..., 2014).

The issues of assessment of efficiency of dual-use technologies projects and relevant financial needs are considered in (Your Guide..., 2014). The impact of development of dual-use technologies on the civil economy is analyzed in (Enger, S., 2014). Rethinking of the approach to assessment of new technologies in the existing environment is made in (Lin, A., 2011). Comprehensive approach to analysis and assessment of new technologies, as well as the responsible research concept are considered in (Bogner, A., \& Torgersen, H., 2014) and (Sutcliffe, H., 2013).

\subsection{Development of tools for assessment of economic efficiency of technologies in Russia}

Before 1970s, assessment of economic efficiency of creation of new technologies in Russia was dominated by the approaches, which were based on the 'cost' category. The standard model of economic efficiency assessment was as follows:

$$
\ni_{(1)}=\frac{\Delta S_{o}}{\Delta K_{o}}=\frac{S_{\sigma}-S_{o}}{K_{o}-K_{\sigma}} \rightarrow \max ,
$$

where $S_{6}$ and $S_{0}$ mean the total cost of products (works) in case of the base and assessed technologies; $K_{6}$ and $K_{0}$ mean capital expenditures in case of the base and assessed technologies.

The period from early 1970s to late 1980s is described by transition to the methods of assessment of economic efficiency of created technologies based on the category of discounted costs, which takes into account (unlike the 'cost' category) the deficit of capital expenditures and the possibility of their realization at different times. The standard model of such efficiency assessment was as follows:

$$
\ni_{(2)}=\Delta 3=3_{\sigma}-3_{o}=\left(S_{\sigma}+E_{n} \cdot K_{\sigma}\right)-\left(S_{o}+E_{n} \cdot K_{o}\right) \rightarrow \max ,
$$

where $3=S+E_{H} \cdot K$ means discounted costs (under the base and assessed technologies, respectively);

$E_{H}$ means the regulatory capital expenditures efficiency ratio.

Assessments of capital expenditures $K_{\sigma}$ and $K_{0}$ were discounted to a comparable form taking into account performance and service life factors using the following formulae:

$$
K_{i}=K_{n p_{i}} \cdot \frac{P_{i}+E_{n}}{B_{i}}+K_{s_{i}},
$$

where $i$ means the index of options under consideration (base and assessed);

$K_{n p}$ means capital expenditures per product unit;

$K_{n p}$ means operations-related capital expenditures per work unit;

$P$ means production cost renovation (amortization) ratio, subject to technology's service life;

$B$ means relative performance.

The renovation ratio was calculated in a simplified way using the following formula: 
$P=\frac{1}{T_{c}}$,

where $T_{c}$ means the technology's service life.

Improved assessment models used another formula, which takes into account the cost discounting:

$$
P=\frac{E_{n}}{\left(1+E_{n}\right)^{T_{c}}-1}
$$

Assessments of capital expenditures were discounted (taking into account different realization time) to the start year using the following formula:

$$
K=\sum_{t} \frac{K_{t}}{\left(1+E_{n n}\right)^{t}},
$$

where $K_{t}$ means capital expenditures in year $t$;

$E_{H n}$ means the costs' discount rate ( $E_{H n} \neq E_{H}$ in most methods which were used at that time).

Models of type (2) largely reflected the realities of that time and approaches specific for the command and administrative system, and, from the standpoint of the modern theory, had many serious faults, including:

- application of different capital expenditures efficiency standards for various industries, determined based on the sector's assigned priorities rather than on the basis of objective assessment of the financial deficit;

- application of different standards for assessment of capital expenditures efficiency and for discounting of costs (such standards should be consistent according to the modern economic theory).

- assumption in respect of fixed and equal results of technology use for all options under consideration (this assumption is good for planning, but is rarely implemented in practice).

- assumption in respect of equality of current production and operation costs for each considered option for all production and operation years;

- assessment of costs based on direct current costs and capital expenditures with no account for various indirect costs and expenses;

- assessment of costs on the basis of the simple planning principle with no direct connection with the real cash flow.

From the late 1980s till present, the tools for assessment of economic efficiency of technologies are based on the opportunity cost concept and UNIDO methodology. Such methodology is based on the following key indicators: net present value - ЧДД (other interpretations of this indicator: integrated effect, present value of an annuity); discounted return on investments - ИДД; internal rate of return - ВНД:

$$
\begin{aligned}
& \text { ЧДД }=Э_{\text {инт }}=\sum_{t=0}^{T}\left(R_{t}-S_{t}^{*}\right) \cdot \frac{1}{(1+E)^{t}}-\sum_{t=0}^{T} K_{t} \cdot \frac{1}{(1+E)^{t}} \\
& \text { ИдД }=\sum_{t=0}^{T}\left(R_{t}-S_{t}^{*}\right) \cdot \frac{1}{(1+E)^{t}} / \sum_{t=0}^{T} K_{t} \cdot \frac{1}{(1+E)^{t}}
\end{aligned}
$$

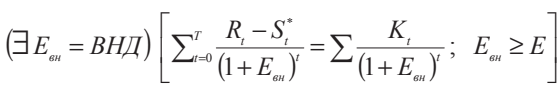

where ЧДД means net present value or integrated effect (Эинт);

$R_{t}$ means the assessed results value in year $t$;

$S_{t}^{*}$ means current costs (without capital expenditures) in year $t$;

$K_{t}$ means capital expenditures in year $t_{\text {; }}$

$\ni_{t}=R_{t}-S_{t}^{*}-K_{t}$ means effect in year $t$;

$E$ means the discount rate used for the results and costs; ИДД means profitability of capital expenditures;

$\exists$ means existential quantifier: $\left(\exists E_{в H}\right) / \ldots \ldots /$ - such $E_{в н}$ exists (is sought), whereby the condition in square brackets is met;

$E_{\text {вH }}$ means the internal rate of return.

Fundamental differences between these indicators and the indicators based on the concepts of cost and simple discounted costs, which are used in prior guidelines, include:

- application of the same discount rate for costs, which takes into account both time and resource scarcity;

- discounting of not just capital expenditures, but also current costs and results;

- - use of various discount rates for different assessed entities, taking into account their economic opportunities and interests (such entities include, but are not limited to customers, consumers, investors, manufacturers, state and its regions, banks etc); 
- use of opportunity cost and implicit cost concepts: this means that not only direct costs, but also indirect losses and lost profits (from potential use of such funds in alternative projects) should be taken into account;

- estimate of results and costs in accordance with the real cash flow (without the costs which are not related to real expenditures (for example, depreciation accrued in the balance sheet when estimating income taxes);

- adjustment for potential unequal distribution by project life cycle phases of not just capital expenditures, but also current costs and results (Kravchuk, P., (2000)).

\subsection{Development of the methodology and tools of economic assessment of technologies in highly developed countries}

In foreign practice, the methods of economic assessment of technologies were developed similarly to their development in domestic practice, but, generally, at a faster pace. Therefore, active adoption of the methods of calculation based on discounted costs took place from 1940-1950s, and application of approaches based on the UNIDO methodology took place from late 1960s (Boer, P.F., 2004).

First of all, we should mention approaches which were widely applied abroad and which are related to assigning the monetary value to the effect, as well as which are related to the use (either directly or in a modified form) of the costbenefit ratio as a criterion for assessment of projects focusing on creation of new technologies. Many methods, which are applied abroad, are based on the well-known Olsen's formula, which is applied on the basis of the rank theory in cases when the target is represented by the technological upgrade (llysheva, N., and Krylov, S., 2014). According to Olsen, the rank of $i$-th project $R_{i}$ may be determined with the following formulae:

$$
\begin{aligned}
& R_{i}=\frac{I_{i} \cdot P_{i}}{C_{i}}, i=1,2, \ldots, n \\
& I_{i}=a \sum_{t=1}^{T} S_{i, t},
\end{aligned}
$$

where I means index of future return;

$P_{i}$ means probability of success;

$C_{i}$ means expected research costs;

Si means anticipated sales;

$t$ means the time period;

$T$ means the time horizon;

$a$ is the strategic parameter, which may be interpreted as the level of return on sales (profit margin).

In case of:

$$
\sum_{i=1}^{T} S_{i, t}=S_{i}^{x}
$$

the efficiency indicator will be used as a rank test, connecting anticipated future sales with anticipated expenses:

$R_{i}=\frac{a \cdot S_{i}^{x} \cdot P_{i}}{C_{i}}$

There were numerous attempts to apply differentiated approach to assessment of uncertainty factors in foreign practice. For example, Kiefer assumes the following factors: $R_{t}$ - probability of getting such technical result; $R_{c}-$ probability of getting such commercial result; $G$ - expected total income; $K$ - total costs of the proposed project (Kiefer, D., 1964). In this case, the general formula will be as follows:

$$
E=\frac{R_{t} \cdot R_{c} \cdot G}{K},
$$

where $E$ is the expected effect (the project is deemed noteworthy, if $E>2$ ).

Formula (14) is good for assessment of the projects, the implementation of which does not bring significant risks and which should be completed within approx. 5 years. Any method, which is applied in order to determine the effect, basically compares the costs and effects. The factors, which are related to preparation and implementation of projects focusing on creation of a new technology, are considered as the cost criteria. In such case, only direct costs of an engineering company (rather than public costs) are taken into account. Results of implementation of this project appear as follows: increase in profit; increase in sales; reduced costs; reduced labor costs; reduced consumption of materials; market expansion; more complete utilization of capital; competitive advantages.

All these criteria are related (either directly or indirectly) to numerous factors which contribute to or prevent from getting relevant results (White, M., and Bruton, G., 2010). Such factors may include: the time factor of result implementation; suitability of new technologies for existing production facilities, materials, markets, organizational 
structures, marketing and sales costs; sales and possible increase in sales (Tutulmaz, O., 2014). Such abundance of factors and criteria means that reduction of profitability analysis to assessment of profitability based on two or three criteria will result in its oversimplification. Determination of changes in costs and sales for different structures of project budgets represents the most important task in selection of an optimal project. More detailed analysis can be made if the probability of projects' success is set as a function of invested money and the estimated present value of future net incomes generated by each project.

The methods applied abroad widely use discounting of effects (results) and costs (Thamhain, H., 2005). Typically, the estimated rate of return and the interest rate, at which financing may be raised for the project implementation, are used as a discount rate. One of directions of improvements in the technologies' efficiency assessment method among Western researchers includes attempts to discontinue using solely monetary indicators of such assessment. Typical examples include well-known formulae of Krauch, H., 1970, and Ansoff, I., 2007. Krauch's formula represents dependence of $L$ efficiency indicator on both monetary and non-monetary factors:

$L=\frac{N \cdot E}{K} \cdot V \cdot S$,

where $N$ means the technology effect during its whole life cycle;

$E$ means the probability of success;

$K$ means total costs incurred prior to putting into operation;

$\checkmark$ means availability of relevant research, engineering and administrative personnel, as well as the research and technical facilities;

$S$ means the strategic value of inclusion into the general program.

Ansoff's criteria is a $c$ quality indicator expressed as:

$M_{p}=\frac{\left(M_{i}+M_{s}\right) \cdot E \cdot P_{s} \cdot P_{p}}{C_{d}+J} \cdot S$

where $M_{i}$ means the technical level;

$M_{\bullet}$ means economic advantages;

$E$ means estimated total revenue for the whole life cycle;

$P_{s}$ means the probability of project success;

$P_{p}$ means the probability of successful market entry;

$S$ means strategic consistency of the proposed project with other projects;

$C_{d}$ means total development costs;

$J$ is the accumulation factor expressed in shared use of existing facilities.

Ansoff uses this criterion along with the following indicator $\Pi_{\kappa}$ :

$\Pi_{\kappa}=\frac{C_{a r}}{F \cdot M_{p}}$

where $C_{\text {ar }}$ means total applied research costs;

$F$ means total costs for additional capacities and labor;

$M_{p}$ means the figure of merit.

Finally, experience in assessment of efficiency of development and implementation of new technologies may be summarized with correlations widely used in the United States for the payback period $O_{k}$ :

$O_{k}=\frac{P_{u} \cdot P_{k} \cdot S \cdot \Pi_{p} \cdot T_{c v u}}{C}$

where $P_{H}$ means the probability of successful research;

$P_{\kappa}$ means the probability of commercial success;

$S$ means the estimated sales (expressed in physical units);

$\Pi_{p}$ means profit per unit;

$T_{\text {cyu }}$ means product life;

$C$ means estimated project cost.

This formula does not take into account the costs related to manufacturing and marketing of products created using new technologies. Such factors are taken into account using a wider profitability indicator:

$\Pi_{p}=\frac{P_{n} \cdot P_{k} \cdot S_{z o d} \cdot Ц T_{c \sigma}}{C+U_{n m o}+U_{n p}}$

where $S_{2 о д}$ means annual sales (expressed in physical units);

$Ц$ means unit price; 
$T_{c \sigma}$ means the period of sustainable sales (years);

$U_{\text {nmo }}$ means manufacturing and engineering costs;

$U_{\text {np }}$ means marketing costs.

Relative value index $\left(\Pi_{c p}\right)$ is a more general index. It includes the breakdown of assessment of the probability of commercial success into the specifications of the new technology and other factors:

$\Pi_{c p}=\frac{P_{u} \cdot P_{\kappa}^{\kappa} \cdot P_{k}^{\jmath} \cdot D_{u} \cdot K_{60}-K_{u}}{C_{n}}$,

where $P_{\kappa}^{\kappa}$ means the probability of commercial success subject to the quality of the technology;

$P_{\kappa}^{\ni}$ means the probability of commercial success subject to economic factors;

$D_{4}$ means net income generated during the technology's life cycle;

Kб means the future revenue factor;

$K_{H}$ means required capital expenditures;

means the total estimated project cost.

Therefore, highly developed countries consider not only efficiency of development and implementation of new technologies, but also the commercial efficiency of their marketing (Garton, C, and McCulloh, E., 2012). However, the values of many used indices are estimated with account for peculiarities of national economies of these countries and, therefore, they are inappropriate for Russia. The most important specific feature of solution to the task under consideration in Russia is represented by the need to account for the specific nature of economic assessment of dual-use technologies.

\section{Methods}

In our opinion, research of the task considered in this article in the light of specific features of Russia's economic development should be based on the methodology of an integrated approach to technical and economic assessment of technology using the overall efficiency concept. The essence of the above approach lies in systematic consideration of the effect from development, implementation and licensing of the technology. Such approach is necessary because new technologies are developed in Russia mostly for the high-tech sector industries: aviation, aerospace, electronics, shipbuilding etc. Many of them are dual-use technologies. They may be used for manufacturing of military and civil products. When implementing the project focusing on creation of a dual-use technology for manufacturing military products, the methods using the above opportunity cost concept and the UNIDO methodology will be applied. However, the above methods do not allow to assess the effect from sale (transfer) of licenses for dual-use technologies from military facilities to civil industries. Existing methods of assessment of technology sharing focus on assessment of the efficiency of international transfer (sale) of technologies. However, they are hardly suitable for solution of the task within the country.

In order to make an economic assessment of sale (transfer) of technologies from military to civil industries, let's assume that the sold dual-use technology $j$ is implemented in a single product, replacing technology $i$, which is also implemented in a single product. When purchasing the license, the consumer pays the cost of the license, as well as some payments related to the license realization, pursuant to relevant contractual terms. Expediency of license purchase for a purchaser will be conditional upon excess of the agreed efficiency criterion (generally, net present value) in option $j$ $\left(\Im_{j}\right)$ over the value of such criterion in option $i\left(Э_{i}\right)$ :

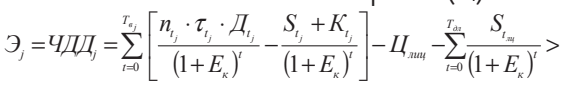

$$
\begin{aligned}
& >\Im_{i}=4 Д Д_{i}=\sum_{t=0}^{T_{k}}\left[\frac{n_{t_{i}} \cdot Д_{t_{i}}}{\left(1+E_{k}\right)^{t}}-\frac{S_{t_{t}}+K_{t_{t}}}{\left(1+E_{k}\right)^{t}}\right]
\end{aligned}
$$

where $T_{\theta_{j}}, T_{\theta_{i}}$ mean product release (technology utilization) periods under options $j$ and $i$;

$n_{t_{j}}, n_{t_{i}}$ mean product release volumes in year $t$ under options $j$ and $i$;

$Д_{t}, Д_{t_{i}}$ mean annual income per unit in year $t$ under options $j$ and $i$;

$\tau_{t_{j}}$ is the ratio describing the risk of obtaining $Д_{t}$ income in year $t_{\text {; }}$

$S_{t_{j}}, S_{t_{i}}$ mean current costs in year $t$ under options $j$ and $i$; 
$K_{t_{j}}, K_{t_{i}}$ mean capital expenditures in year $t$ under options $j$ and $i$;

Цлиц means the license fee, which is paid as a lump sum;

$T_{\partial л}$ is the license validity period;

$S_{t_{u u}}$ means annual current payments to the licensor under the license in year $t$;

$E_{\kappa}$ is the discount rate effective in such market sector.

Let's analyze the obtained correlation. When expressing the net present value of purchased licensed products, the values of production periods, income, current and capital expenditures may and must be significantly better than the same indicators of the base option in order to "redeem" all license payments and risk effects related to implementation of a new technology. Replacing inequality with equality and the license prices with the license trigger price $\left(L_{\text {su }}^{n}\right)_{\text {in }}$ this formula, we may obtain (using the traditional approach) the value of the license trigger price for the consumer (in respect of the current license payments):

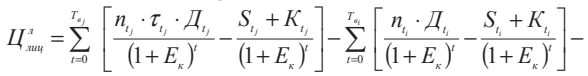

$$
\begin{aligned}
& -\sum_{t=0}^{T_{\omega n}} \frac{S_{t_{u m}}}{\left(1+E_{k}\right)^{t}}
\end{aligned}
$$

However, quite naturally, the license trigger price does not reflect the reasonable price $Ц_{\text {лич }}^{\text {раи }}$ of such purchase it should be significantly lower. It may be determined using of the following formula:

$$
Ц_{\text {suy }}^{\text {pau }}=\frac{Ц_{\text {suu }}^{n}}{1+k_{\text {penu }}},
$$

where $k_{\text {рент }}$ is the benefit-cost ratio acceptable for the purchaser.

If dual-use technology $j$ does not replace dual-use technology $i$, and is implemented independently, then formula (21) may be presented as follows:

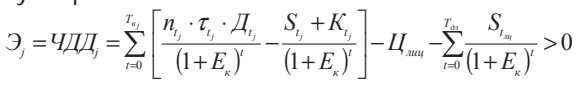

If technology $j$ is implemented for manufacturing of $m$ types of products, formula (24) is transformed as follows:

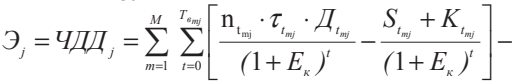

$$
\begin{aligned}
& -Ц_{\text {suy }}-\sum_{m=1}^{M} \sum_{t=0}^{T_{m}} \frac{S_{t_{m m}}}{\left(1+E_{k}\right)^{t}}>0
\end{aligned}
$$

The cases of license sale considered in formulae (21)-(25) relate to the situation, which is quite difficult to estimate, when revenues, production volume and expenses may change from year to year. But in practice they may be often expressed in a form of relatively constant values. Let's assume the case of sale of license $\mathrm{j}$ for dual-use technologies to the civil sector for manufacturing of one type of product, with $n_{t}=$ const $=n, Д_{t}=$ const $=\not, S_{t_{\text {suy }}}=0$ (no current license payment), $\tau_{t_{j}}=0$ (no risks of license use), product $j$ is new and does not replace product $i$.

Efficiency of license purchase for the manufacturer of type $j$ products when applying the net present value criterion will be expressed as follows:

$$
\ni_{j}=\sum_{t=0}^{T_{s}}\left[\frac{n \cdot \not}{\left(1+E_{\kappa}\right)^{t}}-\frac{S_{t}+K_{t}}{\left(1+E_{\kappa}\right)^{t}}\right]-Ц_{\text {mut }}
$$

Generally, total discounted production costs ${ }^{3}$ may be expressed in relation to the full production price:

$3_{n p}=\sum_{t=0}^{T_{s}} \frac{S_{t}+K_{t}}{\left(1+E_{\kappa}\right)^{t}}=\sum_{t=0}^{T_{s}} \frac{n \cdot Ц_{n p}}{\left(1+E_{\kappa}\right)^{t}}$

Considering that:

$$
\sum_{t=0}^{T_{s}} \frac{1}{\left(1+E_{\kappa}\right)^{t}}=\frac{\left(1+E_{\kappa}\right)^{T_{s}+1}-1}{\left(1+E_{\kappa}\right)^{T_{s}} \cdot E_{\kappa}}
$$

formula (26) transforms into: 


$$
\ni_{(j)}=\left(Д-Ц_{n p}\right) \cdot \frac{\left(1+E_{k}\right)^{T_{e}+1}-1}{\left(1+E_{k}\right)^{T_{e}} \cdot E_{\kappa}} \cdot n-Ц_{\text {suи }}
$$

With the knowledge of integrated effects determined for the civil and military sectors where dual-use technology is used $\left(\mathcal{Э}_{i}^{(2 p)}\right.$ и $Э_{j}^{(s)}$ ), we may calculate composite and comparative indicators of integrated effects with account for the both sectors in which dual-use technologies are used. Let's assume that a certain technology is implemented in the civil and military sectors for a single product $-i$ and $j$. Then the total implemented integrated effect of the dual-use technology

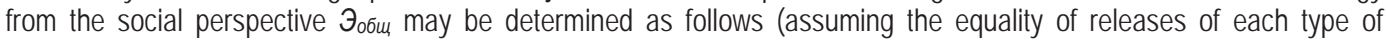
products by production years):

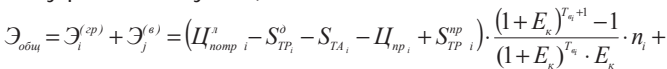

$$
\begin{aligned}
& +\left(L_{j}^{n}-S_{T A_{j}}-L_{n p_{j}}+S_{T P_{j}}^{n p}\right) \cdot \frac{\left(1+E_{c}\right)^{T_{j}+1}-1}{\left(1+E_{c}\right)^{T_{j j}} \cdot E_{c}} \cdot n_{j} \rightarrow \max
\end{aligned}
$$

\section{Results}

The complex approach to economic assessment of technologies requires consideration of essential, specific indicators. The key tasks requiring immediate solution include: clarification of the lists of assessment's key indicators; establishment of basic values for some indicators; determination of weights for indicator groups; determination of relationships between various specifications of technologies; development of technology efficiency assessment methods; testing of developed guidelines and models.

Analysis of technology efficiency is conditional upon utilization of the system of estimates which are based on the assumption that technology development costs have the same economic nature as capital expenditures. Therefore, a new technology creation project must by assessed as an investment project. If inflation is to be factored into the calculation, the formulae for such indicators should be transformed so that inflationary adjustments to the prices are excluded from the values of costs and results; in other words, they should be discounted to the prices of relevant period. Projected price indices and deflators should be used for such purpose. In general terms, selection of the most efficient new technology should be based on comparison of costs and results throughout the whole range of possible efficient capital expenditures of the investor for creation thereof. It should be also noted that the concepts of result and economic effect are not the same, because result may include qualitative components, which can not be subject to economic assessment, or results may include components, the economic assessment of which is not directly included into such result, e.g. economic assessment of social results. Application of selection methods in respect of projects focusing on creation of new technologies, which do not take into account the above circumstances, does not allow to consider peculiarities of analyzed technologies, as well as the time factor to the full extent. In particular, differences in assessment of cash inflows and outflows with different timing are not taken into account. Therefore, the qualimetric analysis of projects focusing on creation of new technologies, which are implemented at different times, becomes more biased. In order to take into account the time factor (which is essential in long-term financial and lending transactions), it is necessary, in our opinion, to determine not just the project completion terms, but also the dates and frequency of cash inflows necessary for development of relevant technology, due to the "unequal value of money" at different time points. Besides, in order to take into account the time factor, we need to apply the discount rate, because discounting is not only an instrument for capitalization of income, but it is also the method of comparison of costs and/or revenues incurred and/or received at different points of time. The following indicators, which take into account the discount rate, may be used: net present value or integrated effect; profitability index; internal rate of return; payback period.

The basic list of the criteria considered in the article is not subject to compulsory application to the full extent when assessing the efficiency of a new technology. A differentiated approach to selection of such criteria should be applied depending on the direction of the technology creation project and its assessment tasks. In order to make a comprehensive assessment, the indicators of technological level should be used in addition to financial and economic indicators (especially in respect of special-purpose technologies).

\section{Discussion}

Determination of correlations between technical and economic parameters of a technology acceptable for practical use is the most difficult and the least studied challenge (Chiesa, V., and Frattini F., 2009). In order to solve this problem, we 
suggest to use the following methods: judgment-based analytical methods; regression analysis; factor analysis; expert opinions. Judgment-based analytical methods are applied in such conditions which are required to establish unequivocal non-random correlations between economic and technical characteristics. Generally, such correlations are established between two variables: e.g. "cost-effectiveness", "cost-development time" etc. In such case, the process of generation of analytical functions is based on the analysis of structural or functional relationships between the studied parameters of technologies or on processing of considered parameters (Schilling, M., 2012). If situation does not allow to establish analytical relationship between random values of economic and technical parameters, regression analysis is applied (Hans, T., 2014).

Regression analysis methods are the most efficient for determining the analytical relationships between costs and technological specifications. However, in order to improve the accuracy of determined relationships, we need large samples, which usually can not be obtained in respect of technologies (Harvard, 2011).

Factor analysis is based on application of regression analysis methods, and this type of analysis is applied whenever we need to assess the impact of deviations of technical specifications (factors) on changes in the cost of technology. With small samples, application of regression and factor analysis methods does not provide the required accuracy in establishing of desired relationships. In such case, in order to solve the task, expert estimates may be used; this method may provide acceptable results with respect to accuracy and reliability, if experts are selected correctly (Mutanov, G., and Yessengaliyeva, Z., 2013), (Tukkel, J. et al., 2011).

We believe that development of methodology and tools for assessment of technologies should be based on realization of the following principles: minimum costs, maximum efficiency, equal significance of estimates and the intrinsic value of technologies. In the current situation, minimum costs and maximum efficiency are the main criteria among them.

\section{Conclusion}

Analysis of development of the methods and models for economic assessment of technologies points out to their consistency. In their economic essence, all of them are based (in the modern context) on the same general methodology of assessment of results and costs in different combinations and modifications thereof. However, existing assessment methods do not allow to assess dual-use technologies in an integrated manner.

Methodological approaches, indicators and algorithms of comprehensive economic assessment of technologies are of general nature. They may be used in all sectors of the Russian economy.

Assessment of the technical and economic efficiency of development of new technologies should include determination of optimal balances between the required costs, creation time and technical specifications. Two principal tasks should be solved in this respect: selection of criteria and indicators, which would allow to make reasonable decisions regarding technology creation; establishing quantitative relationships between technical and economic characteristics. The main requirements to selection of the above criteria include:

- comprehensive technical and economic preliminary analysis, conducted when developing specifications of the technology to be created;

- identification and assessment of technical, economic, social and other components of the effect from creation of a new technology;

- specifying the need for financial and other resources required for creation of a new technology;

- assessment of possibilities of practical application of selected assessment criteria.

- The following may be used as the criteria of technology's priority:

- technology's contribution to large-scale structural changes in production (replacement of underperforming facilities with efficient ones etc.);

- contribution to solution of urgent social and economic problems in the country;

- existence of creditworthy customers interested in development of technologies;

- competitiveness of a new technology in the domestic and global markets;

- projected period of technology development;

- technology developer's research and technological potential, as well as existing technological innovations;

- full costs of technology creation, including investments required for implementation thereof.

Unlike existing methods of solving the task, the developed tools will allow to get an overall assessment of dual-use technologies efficiency with account for the specific nature of their application in various sectors of the economy. However, in order to apply the developed tools more widely, further research efforts need to be taken in order to find solutions to the issues which are not specified in the article (assessment of new technology development risks, import 
substitution efficiency etc.).

\section{Acknowledgements}

This research project was supported by the Russian Scientific Fund (RSF Project No. 14-18-00519).

\section{References}

Andreychikov, A., \& Andreychikova, O. (2015) Sistemnyj analiz i sintez strategicheskih resheniy v innovatike. Osnovy strategicheskogo innovacionnogo menedzhmenta i marketinga [System Analysis and Synthesis of Innovative Strategic Decisions in Theory of Innovations. The Basis for Strategic Innovation Management and Marketing]. Moscow: Librokom [in Russian].

Ansoff, I. (2007) Strategic Management Classic Edition. Palgrave Macmillan.

Balyberdin, V., Belevtsev, A., \& Bendersky, G. (2014) Prikladnye metody ocenki i vybora reshenij v strategicheskih zadachah innovacionnogo menedzhmenta [Applied Methods of Evaluation and Selection of Decisions in the Strategic Objectives of Innovation Management]. Moscow: Dashkov \& Co [in Russian].

Batkovskiy, A.M. (2011) Prognozirovanie i modelirovanie innovacionnogo razvitiya ekonomicheskih sistem [Forecasting and Modeling of Innovative Development of Economic Systems]. Moscow: OntoPrint [in Russian].

Boer, P.F. (1999) The Valuation of Technology: Business and Financial Issues in R\&D. New York: Wiley.

Boer, P.F. (2004). Technology Valuation Solutions. New York: Wiley \& Sons.

Bogner, A., \& Torgersen, H. (2014) Emerging Technologies and the Interpretative Turn in Technology Assessment. Teorija in Praksa, 51 (5), 726-741.

Chiesa, V., \& Frattini, F. (2009) Evaluation and Performance Measurement of Research and Development: Techniques and Perspectives for Multi-level Analysis. Cheltenham: Edward Elgar Pub.

Enger, S. (2014) Dual-Use Technology and Defence - Civilian Spillovers: Evidence from the Norwegian Defence Industry. Master's Thesis. Retrieved from https://www.duo.uio.no/bitstream/handle/10852/35932/Engerx-xMaster.pdf?sequence=1

EU Funding for Dual Use: a Pratical Guide to Accessing EU Funds for European Regional Authorities and SMEs (2014). Retrieved from http://www.czelo.cz/files/EU-funding-for-Dual-Use-Guidebook-2-.pdf.

Garton, C., \& McCulloh, E. (2012) Fundamentals of Technology Project Management. New York: Mc Press.

Hansen, J. R. (1974) A Guide to the Guidelines: The UNIDO Method of Economic Project Evaluation. International Bank for Reconstruction and Development Washington, DC: World Bank staff working paper (Vol. 166). 1974. 216 p.

Hans, T. (2014) Assessing the Effectiveness of Quantitative and Qualitative Methods for R\&D Project Proposal Evaluations. Engineering Management Journal.

Harvard business review on aligning technology with strategy. (2011). Boston, Mass.: Harvard Business Review Press.

llysheva, N., \& Krylov, S. (2014) Bukhgalterskiy uchet, analiz i Strategicheskoye upravleniye innovatsionnoy deyatelnostyu [Accounting, Analysis and Strategic Management of Innovation]. Moscow: Finance and Statistics [in Russian].

Kiefer, D. (1964) Winds of Change in Industrial Chemical Research. Chemical and Engineering News, 42, 88-109.

Konson, A. (1968) Economic of scientific development. New York: Economics.

Krauch, H. (1970) Forschung und Plannung. Berlin: Futurum.

Kravchuk, P. (2000) Metodologiya i metody ekonomicheskoj ocenki, organizaciya rasprostraneniya texnologij i izdelij dvojnogo primeneniya [Methodology and Methods of Economic Evaluation, Organization of Dissemination of Technology and Dual-use Products]. Moscow: Voenizdat [in Russian].

Lin, A. (2011) Technology Assessment 2.0: Revamping Our Approach to Emerging Technologies. Brooklyn Law Review, 76 (4), 13091370.

Metodicheskie rekomendacii po ocenke effektivnosti investicionnyh proektov $\mathrm{i}$ ih otboru dlya finansirovaniya (2-ya redakciya). Utv. Minekonomiki RF, Minfinom RF, Gosudarstvennym komitetom RF po stroitelnoj, arxitekturnoj i zhilishhnoj politike No. VK477 ot 21.06.1999 [Guidelines for Evaluating the Effectiveness of Investment Projects and their Selection for Funding (2nd edition). Approved by the State Construction Committee of Russia, Ministry of Economy of Russian Federation, Ministry of Finance of Russian Federation, Russian Federation State Committee for Industrial Policy. No. VK477 from 21.06.1999]. (1999) Retrieved from http://www.gosthelp.ru/text/Metodicheskierekomendacii20.html [in Russian].

Metodicheskie rekomendacii po ocenke effektivnosti investicionnyh proektov i ih otboru dlya finansirovaniya. Utv. Gosstroem Rossii, Minekonomiki RF, Minfinom RF, Goskompromom Rossii 31 marta 1994, No. 7-12/47 [Guidelines for Evaluating the Effectiveness of Investment Projects and their Selection for Funding. Approved by the State Construction Committee of Russia, Ministry of Economy of Russian Federation, Ministry of Finance of Russian Federation, Russian Federation State Committee for Industrial Policy. March 31, 1994 No. 7-12/47]. (1994) Retrieved from http://sniphelp.ru/constructing/002.008.001 [in Russian].

Mutanov, G., \& Yessengaliyeva, Z. (2013) Development of Method and Models for Assessing Innovativeness and Competitiveness of Scientific - Innovative Projects. World Applied Sciences Journal 23 (9), 1192-1200.

Postanovlenie GKNT SSSR No. 60, prezidiuma AN SSSR No. 52 ot 03.03.1988 "Ob utverzhdenii "metodicheskih rekomendacij po kompleksnoj ocenke effektivnosti meropriyatij, napravlennyh na uskorenie nauchno-texnicheskogo progressa" [Regulation of the State Committee of the Council of Ministers of Science and Technology of the USSR number 60, Presidium of the USSR from 
03.03.1988 No. 52 "On approval of the Guidelines on Integrated Assessment of the Effectiveness of Interventions Aimed at Accelerating Scientific and Technological Progress"]. (1988) Retrieved from http://www.bestpravo.ru/sssr/gn-praktika/d8a.htm [in Russian].

Schilling, M. (2012) Strategic Management of Technological Innovation. New York: McGraw-Hill//rwin.

Sutcliffe, H. (2013) A report on Responsible Research \& Innovation (On the Basis of Material Provided by the Services of the European Commission. Prepared for DG Research and Innovation, European Commission). Retrieved from http://ec.europa.eu/research/ science-society/document_library/pdf_06/rri-report-hilary-sutcliffe_en.pdf.

Thamhain, H. (2005) Management of Technology: Managing Effectively in Technology-Intensive Organizations. New York: Wiley.

Tukkel, J., Yashin, S., \& Makarov, et al. (2011) Razrabotka i prinyatie resheniya v upravlenii innovaciyami [Development of Solutions and Decision-Making in the Innovation Management]. Sankt-Peteburg: BHV-Petersburg [in Russian].

Tutulmaz, O. (2014) The Relationship of Technical Efficiency with Economical or Allocative Efficiency: Evaluation. Journal of Research in Business and Management, 2 (9), 1-12.

White, M., \& Bruton, G. (2010) The Management of Technology and Innovation: A Strategic Approach. Boston: Cengage Learning.

Your Guide to European Structural Funds for Dual-use technology projects (2014). Retrieved from http://www.gsrt.gr/News/Files/ New1002/EDA-ESIF_RfP-Applicant_rules-Appendix6.3_ESIFHandbook.pdf. 